\title{
Institutions and the transition to adulthood: Implications for fertility tempo in low-fertility settings
}

\author{
Ronald R. Rindfuss and Sarah R. Brauner-Otto*
}

\begin{abstract}
The number of countries experiencing very low fertility has been rising in recent years, garnering increasing academic, political and media attention. There is now widespread academic agreement that the postponement of fertility is a major contributing factor in the very low levels of fertility that have occurred, and yet most policy discussions have been devoted to increasing the numbers of children women have. We discuss factors in three institutions - the educational system, the labour market and the housing market - that may inadvertently have led to childbearing postponement. We highlight important components of the timing of childbearing, including its changing place within the transition to adulthood across countries and the significance of the demands of childbearing versus childrearing. Using illustrations from Europe, North America, Japan, Australia and New Zealand, we argue that the following all lead to younger childbearing: 1) an open education system whereby it is relatively easy to return to school after having dropped out for a while; 2) a shorter, smoother, easier school-to-work transition; 3) easier re-entry into the labour market after having taken time out for childrearing or any other reason; 4) greater capability of integrating childrearing into a career; 5) easier ability to obtain a mortgage with a moderately small down payment, moderately low interest rate and a long time period over which to repay the loan; and 6) easier ability to rent a dwelling unit at an affordable price. Conversely, reversing any or all of these factors would lead, other things being equal, to postponement of childbearing.
\end{abstract}

\footnotetext{
* Ronald R. Rindfuss (author of correspondence), East-West Center, 1601 East-West Road, Honolulu, HI, USA and Carolina Population Center, University of North Carolina, CB\# 8120, University Square, 123 West Franklin Street, Chapel Hill, NC, USA. Email: ron_rindfuss@unc.edu

Sarah R. Brauner-Otto, Carolina Population Center, University of North Carolina, Chapel Hill, NC, USA.
} 


\section{Introduction}

There has been considerable academic, political and media attention to the phenomena of very low fertility levels. In countries such as Germany, Austria, Italy, Spain and Japan, concern has centred on the potentially deleterious budgetary effects for social programs for the elderly, business anxiety over having a sufficient labour supply, the realisation that immigration is a difficult fix, and nationalistic fears related to declining populations. These concerns, coupled with a long period of low fertility, have induced extensive discussion on whether countries with low fertility should introduce explicit policies to increase fertility and, if so, what policies might be successful.

Within the demographic research community there is now widespread agreement that timing changes are a major component of the very low levels of period fertility in many countries (Bongaarts and Feeney 1998). If women start having their children at younger ages, as was the case during the US 'baby boom' of the 1950s, the period total fertility rate (TFR) will be higher due to this timing change (Ryder 1980). On the other hand, if women start having their children at later ages, as has been happening in most developed countries in the past two decades, the tempo effect deflates the period TFR. Figure 1 shows the increase in the mean age of women at the birth of their first child for a variety of countries. ${ }^{1}$ The consistent and steady upward slope of every line is evident. Further, there is still room for considerable additional postponement. Even if there had been no change in the actual number of children women were having over the course of their childbearing years, this postponement of childbearing would have led to lower period fertility rates.

Despite agreement on the relationship between tempo changes and period TFRs, and the concern over very low period fertility levels, there has been little discussion of variations in social institutions that might affect fertility tempo, and more specifically the timing of the first birth (cf. policy discussions in Gauthier 2002; Hantrais 1997, 1999; McDonald 2003). An exception is Lutz and Skirbekk (2005) and even they devote more attention to a set of hypothetical projections demonstrating the magnitude of the effect of a cessation of postponement than to the nature of factors that might reduce fertility postponement. In this paper we discuss aspects of three institutions (education, labour market and housing market) related to the timing of the first birth. We provide a framework for understanding how these institutions might affect fertility tempo. This institutional/policy framework, in turn, lays the foundation for future empirical analyses - an issue to which we return in the conclusion.

1 Thanks to Tomáš Sobotka for providing the data used in Figure 1. 
Figure 1:

Mean age of women at birth of their first child for selected countries, 1980-2006

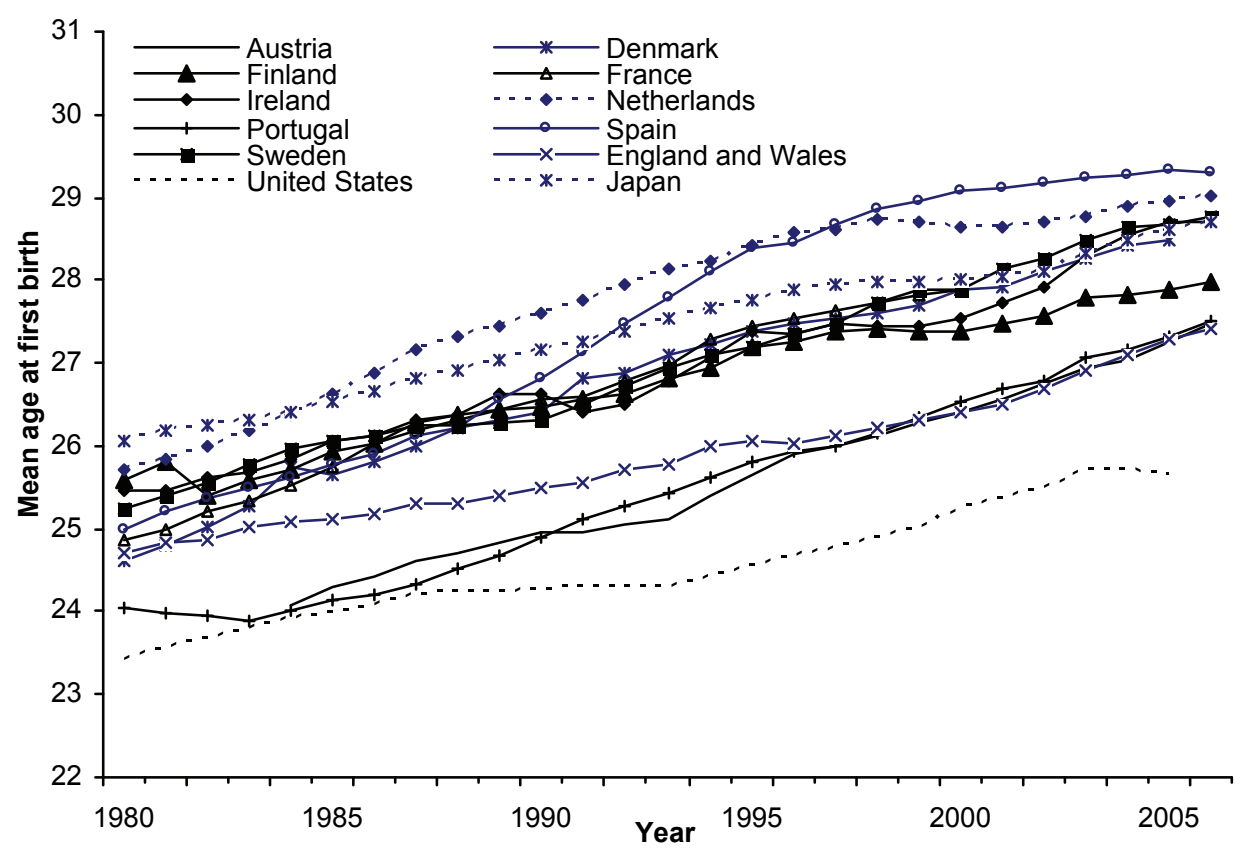

Source: Council of Europe (2006), computations based on birth and population data from Eurostat (2008) and national statistical sources

We consider countries that had fertility levels approaching replacement level by the end of the 1970s and did not have a history of communist rule. The countries include western Europe, North America, Japan, Australia and New Zealand. The communist history in eastern Europe adds an additional layer of complexity that is beyond the scope of this paper. We also do not include such countries as Singapore or South Korea because the recency of their fertility declines makes it more difficult to consider the types of institutional factors discussed here. We limit our attention to the transition to parenthood, i.e. the timing of the first birth. This is arguably a more momentous fertility decision than those involved in subsequent parities in that the first child dramatically changes the constraints facing an individual and a couple, and it substantially influences the time-use patterns of young adults, especially women (Gauthier and Furstenberg 2002).

In this paper we put forth two basic, interrelated propositions. First, any factor that eases entry into various adult roles will lead to younger childbearing, and conversely, any factor that postpones entry into various adult roles will postpone childbearing. Second, any factor that allows a young adult to more easily juggle multiple roles will lead to younger childbearing. 


\section{Institutions and Policies}

We begin by defining a few terms used throughout the paper. First, institutions. Institutions are the set of norms or rules, formal and informal, which guide relationships among role occupants in areas of structured social interactions and organisations. Institutions influence social relations, and social relations, in turn, affect institutions. Second, policies. Policies are formal norms or rules within institutions, and exist until formally changed. Consider the example of tracking students in schools. If a school system very informally placed kids with more ability in more challenging classes, that would be tracking, it would be part of the educational institution, but it would not be a policy. On the other hand, if the school board mandated that the bright kids be given special challenging educational opportunities, e.g. the so-called "gifted and talented" programs in many US schools, that would also be tracking, it would be part of the educational institution, and it would be a policy.

For a variety of reasons the evaluation of the effects of policies, and institutions more broadly, on fertility timing is extremely difficult. An initial issue is the proper unit of analysis. While children are born by individual women, policies are decided and implemented by macro-level units, and these macro-level units need to be incorporated into any formal evaluation analysis. In this paper we focus on aspects of the educational system, the labour market and the housing market. Arguments could be made that the appropriate macro units for studying these institutions are multi-country units (e.g. the Norwegians and the British have had impacts on the housing market in Spain's Mediterranean region, as have the Japanese in Hawaii, and most European Union countries share the same currency, with fluctuations in the Euro affecting all inhabitants of those countries) or sub-national units such as provinces or cities (e.g. educational policies are often made at the local level and numerous aspects of labour markets are localised). Further, some countries are geographically divided along ethnic, religious or linguistic lines, and these divisions, in turn, influence policies and institutions.

Having acknowledged the importance of multi-national and sub-national units for the policies and institutions discussed in this paper, the country level is likely to be the most important and the one on which we focus. Major educational policies, such as educational requirements for various professional occupations or the nature of the interface between the educational system and the labour market tend to be set at the national level. Numerous factors affecting the labour market, such as minimum wage, immigration policies, maternity leaves, who pays for health care and the ease with which an employer can fire an employee, are also typically set at the national level. Similarly, national banks have substantial influence on setting mortgage rates and required down payments, and national laws/courts affect the level of discrimination in the housing market. 
Unfortunately, because only a small number of countries have had low fertility for a generation or more and because there are a large number of variables of potential interest, empirical analyses suffer from a degrees-of-freedom problem. DiPrete and his colleagues (2003) creatively approach this problem by examining, one variable at a time, the relationship between fertility levels and multiple aspects of the cost of children. The problem with their approach, of course, is that multivariate control is not possible. Another solution is to look for situations where policies that might affect fertility are enacted or implemented at the local level. In a recent paper (Rindfuss et al. 2007), we found that the availability of affordable, high-quality child care led to younger ages at first birth in Norway. This research was possible because the national policy to make child care more available was implemented unevenly across Norwegian municipalities.

If countries implementing a new policy did so using an appropriate experimental design it would be easier to evaluate its effectiveness. But, if we assume that a new policy is popular and desired by the population, then regions selected to be the 'control group' would probably be upset about not receiving the benefits. In such a situation the political price to be paid for the experimental design would probably not be worth it to policy makers and this is likely to be a main reason why the low-fertility literature does not have good examples of deliberate policy experiments.

An additional evaluation difficulty is that policies are not randomly assigned to countries. Rather countries enact policies and develop informal aspects of institutions that are in keeping with their national character, that is, such factors as culture, history, ideology and religion (Breen and Buchmann 2002). This creates path dependence making it difficult to disentangle aspects of national character from the effects of a given institution. To take the case of child care availability in Norway mentioned above, it is important to remember the Norwegian emphasis on egalitarianism. The increase in child care centre availability was motivated by a preference to create a situation where women could participate in the labour force as much as they wanted (see the discussion in Bernhardt et al. 2008). Hence child care centres have modest charges for parents, are open every work day during normal working and commuting hours and maintain very high standards for both the physical facility and the qualifications of the day care workers. How effective an increase in child care availability would be in a setting that did not emphasise egalitarianism is unclear.

Another difficulty in evaluating policies is that births can occur over a period that spans roughly 35 years in a woman's life and even longer in a man's. Some policies and other aspects of institutions may be more effective or relevant at parents' younger ages, such as lowering the conflict of going to school and being a parent, others at later ages, such as the availability of quality child care during working hours (Rindfuss et al. 2007).

Finally, most of the policies and other aspects of institutions discussed here were not put into place to specifically influence fertility and its timing, but rather 
to influence learning, work or housing. Hence, any effects on fertility were likely inadvertent, and quite possibly unanticipated. Partly as a result of these features of policies and their evaluation we do not attempt a specific cost-benefit evaluation of given policies and institutions. Instead, we provide the reader with an overview and framework that may be helpful in guiding future empirical research.

\section{The importance of timing}

With the work first of Hajnal (1947 as discussed by Ní Bhrolcháin 1992) following World War II, and then Ryder (1956, 1980) and most recently Bongaarts and Feeney (1998), there has been a tendency, sometimes explicitly, to dismiss childbearing timing changes as 'mere' timing changes. The suggestion is that, if there is continuity in underlying cohort fertility, we need not concern ourselves with timing changes because the number of children born per woman will remain the same. This raises three issues worth considering briefly. First, timing changes strongly influence cohort size, that is, the number of children born in any given time period. Perhaps the most famous example was the beginning of the US baby boom. In 1947 there were 35\% more births than in 1945-3,699,940 versus 2,735,456 (National Center for Health Statistics, 1975, Table 1). This increase was primarily the result of timing changes (Ryder 1980), and these 'mere' timing changes had profound implications for the cohorts involved. For example, even though school systems across the country had 5 years to get ready for the increased numbers of children, many communities had to resort to split sessions, with some children going to school in the morning and others in the afternoon. ${ }^{2}$ Now, some 60 years later, government-run pension systems are bracing for the retirement of the baby boom generation.

Second, there is a potential feedback loop through the "low-fertility trap" hypothesis (Lutz and Skirbekk 2005; Lutz et al. 2006). The idea is that postponement of fertility produces small cohorts, and children from these small cohorts may grow up knowing many adults who had only one child or no children. Their childhood experiences influence their own fertility preferences, and when they reach childbearing age a substantial proportion have childbearing preferences in the range between 0 and 1 . While strong empirical support for the low-fertility trap hypothesis does not yet exist, the hypothesis is consistent with empirical evidence showing a positive link between parents' and children's fertility preferences and behaviour. Women who grew up with few siblings tend to have fewer children themselves (Anderton et al. 1987; Axinn et al. 1994; Johnson and Stokes 1976; Murphy and Knudsen 2002; Murphy and Wang 2001),

2 A ProQuest search of the New York Times from 1951-1955 found 13 stories dealing with students in double- and even triple-session situations. Five of these stories were on the front page. 
Further, there is a positive correlation between the timing of parents' fertility and the timing of one's own childbearing (Steenhof and Liefbroer 2008).

A third point is that there is considerable evidence that timing and number issues are positively correlated: later means fewer (e.g. Kohler et al. 2002; Marini and Hodson 1981; Morgan and Rindfuss 1999). Typically, those who remain voluntarily childless do so through a series of postponements and then eventually deciding not to have any children, rather than deciding at a relatively young age to remain childless (Veevers 1971). Ultimately, however, postponement can run into the biological end of the reproductive period. In fact, the strongest effect of the timing of childbearing on completed fertility is likely to occur when women and men have delayed past the point where it is possible for them to have children.

\section{Childrearing not childbearing}

Parenthood can be divided into two consecutive parts: childbearing and childrearing. Few would describe pregnancy and childbirth as being easy. Morning sickness is experienced by many early in pregnancy and the later weeks of pregnancy involve discomfort associated with doing everyday activities while carrying a soon-to-be-born fetus. An example of the latter comes from qualitative work in Tokyo which found that pregnant women complain about the uncomfortableness of commuting on extremely crowded Japanese subways during the last trimester (Roberts 2007). Overt discrimination against pregnant women in the workplace was historically common and, in many countries, continues to be so today (Cunningham and Macan 2007; Hanlon 1995; Masser et al. 2007). And, despite obstetric advances, there still are serious health risks associated with pregnancy.

However, childrearing occurs over a much longer time frame and it is the childrearing role, especially the mother role, which generates incompatibility with other roles, such as student or worker. Anything that reduces this incompatibility would make it easier to rear a child; and, other things being equal, the easier it is to rear a child, the greater the likelihood that men and women will become parents at younger ages.

There are two separate aspects of caring for children, active care and supervision. A number of papers in recent years have shown that, despite the enormous increase in the per cent of mothers in the paid labour force, there has actually been an increase in the time mothers spend caring for their children (Bianchi 2000; Bianchi et al. 2006; Gauthier et al. 2004). These papers, however, are talking about 'active child care,' that is, time when the mother's primary activity is caring for her child, such as playing with the child or changing its diaper. Such measures do not include other supervisory time when the mother might be cooking, for example, while keeping an eye out for her child (e.g. Folbre et al. 2005), nor do they include time when the child is sleeping but still requires 
supervision. The amount of time mothers spend in active child care is commonly in the 2 to 3 hours per day range, but it is important to remember that infants, toddlers and young children need 'supervisory care' 24 hours a day, 7 days a week. Supervisory child care need not be always be performed by the mother, but in most cases she has responsibility for ensuring that appropriate supervision is in place (e.g. England and Folbre 2005).

The age at which a child needs less supervision varies depending on the values of a society or a group within a society, the context where a child is being reared and characteristics of the child. Consider context first. The safer the context, the younger the age at which a child needs less supervision. Aspects of 'safety' of a context can range from the level of crime in a neighbourhood to the amount/speed of traffic to the number of adults/older children in the neighbourhood who know the child and are willing to perform informal, 'as needed', supervision. Various organisations, such as child care centres, schools, summer camps, religious instruction and local youth organisations can also provide supervision. Further, societies have values regarding the age when children can be unsupervised for part or all of the day. Sometimes these values get codified such that social welfare agencies will get involved if parents are not providing adequate supervision, but more importantly it is understood by everyone when it might be acceptable to leave a child unsupervised. And, these values vary across societies. For example, in parts of Scandinavia it is common for a parent to leave a sleeping infant in a pram outside a small shop while the mother goes inside to buy something. In Scandinavia the child is perfectly safe in the pram, but in American cities of comparable size this would be considered inappropriate parental behaviour and could lead others to report that behaviour to a local social welfare agency. ${ }^{3}$

Characteristics of the child might also affect the nature of the supervision required. This involves more than the obvious age of the child. Some children might have personality traits (e.g. a tendency to take risks) or nocturnal afflictions (e.g. sleep walking) that affect the nature of supervision required-and these characteristics of the child, of course, are not known until after the child is born and starts developing.

Clearly, anything that reduces the parental, especially the maternal, supervision burden would make it easier to raise a child; and anything that makes childraising easier makes it easier to do so at a younger age. The most common

\footnotetext{
A case that was well-publicised in the international press illustrates this point. On May 10, 1997, a Danish mother, Anette Sorensen, and her boyfriend were having a drink in the East Village section of New York City while her 14-month old daughter was sleeping outside in a pram in front of the restaurant window. While leaving a sleeping child in a pram outside a shop or restaurant in not unusual in parts of Scandinavia, it is considered inappropriate behaviour in New York City. A restaurant patron called the police. Ms Sorensen and her boyfriend were arrested and locked up for 48 hours while her daughter was cared for by social services. Matters were eventually straightened out and Ms Sorensen later sued the city. This case clearly, if not extremely, illustrates variability in norms about supervising children.
} 
strategy for reducing parental supervisory time is the use of child care centres, and there is clear evidence that the increased availability of affordable, high quality child care centres leads to younger ages at the transition to parenthood - at least in Norway (Rindfuss et al. 2007). ${ }^{4}$ There are also a variety of other strategies to reduce the supervisory burden, or to reduce the worker-parental supervisor conflict, including help from the other parent and from relatives, having one of the parents do shift work (Presser 1988), the availability of part-time jobs which are financially rewarding, cognitively challenging and psychologically fulfilling, school hours that are convenient for the parent and various after-school and summer programs.

\section{The transition to adulthood}

Becoming a parent is a component of the broader transition to adulthood - a stage of the life course that has received considerable attention in North America and Europe recently. ${ }^{5}$ While well-known, it is important to reiterate that the young adult years are a period of the life course when multiple transitions are occurring in the educational, work, residential and family spheres. Not only do these various transitions overlap in time, but they are increasingly delayed and their order has become increasingly varied (e.g. Cook and Furstenberg 2002; Elzinga and Liefbroer 2007; Mouw 2005; Settersten 2007; Shanahan 2000). We will not summarise and critique the transition to adulthood literature except to make several observations that are especially germane to arguments in the remainder of this paper.

Combined with temporal overlap and order variability is causal ambiguityor, to use a different terminology, these processes are endogenous. Pick any pair of transitions mentioned above and it is easy to argue how they might influence each other, as well as both be influenced by a common set of unmeasured variables. As a result, analyses that take one of these transitions as a dependent variable and treat the others as independent (exogenous) time-varying variables are common in the transition to adulthood research literature and their results may be biased. From the perspective of the present paper, caution needs to be exercised in interpreting event history analyses of age at first birth that do not satisfactorily take into account these very difficult endogeneity issues.

While acknowledging the concern with endogeneity, it is also important to recognise that social norms play a role in the sequencing of events. Consider the

4 But if, for example, the hours child care centers are open are not compatible with holding a fulltime job, then the availability of child care centers might not influence the timing of parenthood (e.g. for Germany, see Hank and Kreyenfeld 2003).

5 See papers in the following: Volume 580 of the Annals of the American Academy of Political and Social Science; Volume 23 (3-4) of the European Journal of Population; Blossfeld et al. 2005; Corijn and Klijzing 2001. 
relationship of childbearing to aspects of the education and work spheres. More than 30 years ago, in commenting on US childbearing norms, Ryder (1973, p. 61) put qualifiers on the normative imperative to become a parent:

“...norms specify that all people are expected to marry and have two children as soon as, and providing that, their economic circumstances permit. The economic constraint is couched in terms of the scale of living to which they aspire."

Ryder was only referring to the United States, but we expect that his argument is also valid for other countries considered in this paper. Similarly, Mulder (2006a) argues that in some countries it is expected that young men and women should be home owners (or in a position to soon purchase a dwelling unit) prior to becoming a parent. The general point is that the stronger the norms about the transitions that should occur prior to becoming a parent (finishing school, obtaining a job, marrying, purchasing a dwelling unit), the later the transition to parenthood is likely to occur. And further, anything that postpones these prerequisite transitions will also postpone parenthood. ${ }^{6}$

A final point involves cross-national analyses. An exciting development has been the emerging availability of comparable event-history or biographical data for a variety of countries permitting cross-country comparisons (e.g. Elzinga and Liefbroer 2007; Nicoletti and Tanturri 2008; Frejka and Sobotka 2008). These analyses show strong differences in the nature of the transition to adulthood across countries. Typically, southern European countries cluster as do the Scandinavian countries. The challenge will be to theoretically identify institutional factors that lead to country differences as well as country clusters, and then empirically test such hypotheses. Towards that end, the remainder of this paper presents arguments about country-level aspects of educational systems, labour markets and housing markets that might affect the timing of parenthood. Testing these hypotheses will have to await future research.

\section{Education}

In the countries under consideration here, education (its timing, content, credentials and philosophy) has come to occupy an ever more important part of the young adult years of men and women. Educational systems differ considerably across countries along myriad dimensions, including age at beginning of formal instruction, the ease with which one can re-enter after having dropped out for a while and the extent to which the educational system plays a

\footnotetext{
While we do not have the empirical evidence to demonstrate it, we expect that the postponement of prerequisite transitions in countries with strong norms about them is behind the emergence of the strong, positive correlation between the proportion of births that are nonmarital and that country's total fertility rate (Billari and Kohler 2004). In essence, non-marriage can be a barrier to childbearing and when marriage has diminished as a prerequisite, the timing of childbearing decreases or, at least, does not increase as much as it would have otherwise.
} 
role in obtaining jobs for its graduates. Before discussing these and other aspects of the educational system, it is important to recognise the dramatic changes that have occurred in educational attainment.

Educational enrolment has increased both in terms of the per cent of young people participating and their length of involvement with the educational system. For all the countries considered in this paper, the per cent with more than the minimum required education has increased - in many cases by more than 100 per cent from the 1950s to today (Klijzing 2005). In Italy, for example, the per cent of school leavers who had secondary or university degrees increased from less than 20 per cent to roughly 60 per cent from the 1950s to the 1980s (Bernardi and Nazio 2005). These changes have also been apparent for lower levels of education - in France, the per cent of young people from working class families who obtained a high school diploma increased from 10 per cent in the 1950 s to 46 per cent in the late 1970s (Kieffer et al. 2005).

Education has also become important for family and fertility behaviour. First, the spread of education across the population and the increase in higher levels of attainment has pushed the completion of education well up into the childbearing years. Since it is difficult (even if programmes are available to ease the role conflict) to combine being a student with either the time-consuming aspects of caring for a child or working full time to be a fiscally responsible parent, the increase in education has tended to further postpone childbearing. For virtually every country included in this paper students have the lowest fertility rates (e.g. Blossfeld et al. 2005), and there is scattered evidence that educational differences in age at first birth have been increasing (Ekert-Jaffé et al. 2002; Kravdal and Rindfuss 2008). Further, increases in female educational attainment may have also led to women's preference for establishing themselves in the labour market prior to becoming mothers. In critiquing Becker's (1981) specialisation model, Oppenheimer $(1988,1994)$ argues that it is a pooling of resources that now produces benefits from living in a union and makes rearing children more feasible. Hence, better educated women may now be more likely to delay childbearing to establish a career, as has traditionally been the case for men. There is some empirical support for Oppenheimer's argument in France (WinklerDworak and Toulemon 2007) and Norway (Kravdal and Rindfuss 2008).

One dimension on which educational systems differ is the age at which children start and can legally finish formal schooling. Lutz and Skirbekk (2005) suggest that starting schooling at a younger age would lead to a younger age at graduation and to an earlier start of childbearing. This premise is based on work by Skirbekk and colleagues (2004) — using Swedish registration system data, and taking advantage of the fact that children are enrolled in school during the calendar year they turn 7, they show that those born in December have their first birth approximately 5 months later than those born in January of the same calendar year. The basic hypothesis in both papers is straightforward: a younger age at graduation leads to an earlier start of adult transitions, including 
parenthood. On the other hand, there is evidence that those who are relatively old in any given grade or level of school, e.g. the January births in the Swedish case, tend to gain more self-confidence (Alton and Massey 1998; Sharp 1995) which could postpone childbearing. Indeed, in the Swedish data examined by Skirbekk and colleagues (2004), those born in the first half of the year had a higher probability of attending college than those born in the second half, and this additional time in schooling may lead to a later transition to parenthood.

\section{Education: re-entry}

In addition to the timing of the start of schooling, education systems differ in their openness, that is, the extent to which it is possible to return to school once one has left for a period of time, and the ease with which one can do so. The conventional life course model is to finish all of one's schooling prior to 'settling down' and having children. And this is still the experience of the vast majority of young adults in the countries covered in this paper (Corijn and Klijzing 2001). Yet the spread of education further and further into young adulthood raises the question of whether flexibility in returning to school might influence fertility timing (cf. Hoem et al. 2006a). We would hypothesise that the more open the educational system, that is, the easier it is to return after having left school for a semester or more, the higher the probability that young men and women become parents earlier (and then return to school when their children are a little older and appropriate child care arrangements have been made).

Countries differ substantially in the extent to which such breaks in schooling (stopping and then returning) are common. In Norway, for example, where the educational system is open and flexible, based on the educational histories of all members of the birth cohort of 1964 who became parents, 21 per cent of the women and 20 per cent of the men had a higher level of completed education at age 39 than when they first became parents (Kravdal and Rindfuss 2008). By contrast, in Japan, looking at ages 20-30 for birth cohorts 1960-1970, only 1 per cent returned to school after being out of school (Rindfuss et al. 2008). To pick another example, at ages 30-39 in New Zealand 12 per cent are enrolled in school compared to 3 per cent in Italy (OECD 2006, Table C1.2). We do not have uniform measures of the openness of educational systems for the full range of countries of interest in this paper, but we note that Norway and New Zealand have relatively young ages at first birth compared to Japan and Italy. There are a wide variety of other differences across these four countries, but our general expectation is that, other things being equal, a more open educational system will yield a younger age pattern of childbearing because people know they can return for more education.

Work by Hoem and his co-authors (2006b) suggests that field of study interacts with the relationship between openness of the educational system and 
age at first birth. Using Swedish data, they find that women who are in such traditionally female educational tracks as primary school teacher, nurse, child care worker or special-education teacher have a mean age at completion of education several years older than their mean age at first birth; the opposite is the case for those women who pursued other fields of study. The openness of the Swedish educational system coupled with the family-friendly nature of these female career paths may allow them to become mothers at a younger age than might otherwise have been possible.

\section{School-to-work transition}

The school-to-work transition is key in the transition to adulthood, providing young women and men the confidence that they can afford to become parents. For now, put aside the possibility that in some settings the school-to-work transition can occur multiple times and that mothers who leave the labour force face an additional work transition if they plan to return after their child(ren) reach(es) an age at which the mother feels comfortable returning to work.

The school-to-work transition is at the intersection of two institutions and is consequently affected by both, including aspects of the education system that influence the characteristics of the supply of labour market entrants, aspects of the labour market that affect the demand for new hires and the matching process itself (Bernardi et al. 2004; Breen 2005; Kerckhoff 1995; Müller 2005; Wolbers 2007). We discuss each, but the general hypothesis is that the shorter, smoother and easier the school-to-work transition, the earlier the transition to parenthood.

Educational systems differ in the extent to which they train students for specific jobs in the labour force (vocational specificity), stratification (the extent to which students are sorted into different tracks) and standardisation across schools within a country. With respect to vocational specificity, the United States, Sweden, Spain and Italy are examples of countries with relatively little training for specific jobs and where employers consider educational credentials simply as an indication of trainability (Bernardi et al. 2004; Bernardi and Nazio 2005; Bygren et al. 2005; Noguera et al. 2005). Germany, by contrast, offers more than 300 specific vocational/apprenticeship tracks (Cook and Furstenberg 2002; Wolbers 2007), and evidence from several countries suggests that young people who had apprenticeships obtained full-time jobs significantly faster than young people without apprenticeships (Kurz et al. 2005; Nilsen 2005). Hence, more vocationally-specific educational systems may lead to earlier childbearing. But under certain conditions such specificity may also yield a substantial mismatch between labour supply and demand, leading to under-employment or longer spells waiting for an appropriate job opening, and, thus, probably to delayed childbearing. Further, it is also important to recognise that signals from vocational 
tracks can be difficult to read. In Italy, for example, some vocational education is used to merely hold students until the end of compulsory schooling (Breen 2005).

Standardisation of an educational system refers to the extent to which credentials from different schools within a country have the same country-wide meaning in terms of mastery of a given body of knowledge, thus providing employers with an indication of their potential productivity (Scherer 2005). Schools in the United States (both secondary and tertiary) are locally controlled and funded, and there is limited standardisation across schools (Kerckhoff 1995). Spain and Italy are also characterised as having low standardisation (Bernardi and Nazio 2005; Noguera et al. 2005). Germany and Austria, on the other hand, have a high level of standardisation and are among the best at providing clear indicators of students' abilities/knowledge/training to prospective employers (Breen 2005).

In addition to variability in educational institutions, there is also variability in labour markets, their demand for new entrants, the protection of current employees and the market strategies of national firms. ${ }^{7}$ Demand for new entrants depends partly on the state of the economy as well as on more persistent aspects of the labour market. One crucial aspect of the labour market is the extent to which firing an employee is subject to strict and (from the employer's perspective) cumbersome regulation. If current employees are protected then young people leaving school will have a more difficult time finding a job because employers are reluctant to hire in the event that business conditions deteriorate or the young person does not turn out as anticipated. For example, Spain, Italy and Greece have a high degree of protection of current employees. In these southern European countries, among those leaving school only one-quarter have a job within the first year of leaving school (Wolbers 2007) and approximately 40 per cent are unemployed or inactive five years after leaving school (Brzinsky-Fay 2007). Other things being equal, we expect these long search times to delay childbearing.

In many countries, one response to the high protections offered to existing employees has been the development of fixed-term, training, or contract positions (Klijzing 2005). These positions are, by definition, less stable and less rewarding. They also have lower firing costs making them attractive to businesses facing more intense competition associated with globalisation. In countries with high labour protection, young people are increasingly transitioning from school to these less secure positions. For example, in Spain 10 per cent of jobs in 1984 were classified as fixed-term or temporary. By 1995 one-third of all jobs fit into this category and 70 per cent of them were filled by workers under age 25 (Noguera et al. 2005). Or, to take another example, in Japan employers are moving away from the lifetime employment model (e.g. Roberts 2007; Yuji 2005). This has resulted

\footnotetext{
7 The discussion here is focused on young adults, but it draws on the broader insider-outsider theory, and the nature of turnover costs. For a review of this broader theory see Lindbeck and Snower (2002).
} 
in the rise of employees working in temporary positions as keiyaku (those hired under a fixed-term contract with limited provisions of social insurance and other fringe benefits) and haken (contract work whereby an agency sends workers to a corporation for a specified period) (Statistics Bureau 2001). These non-regular workers tend to be young: $61 \%$ of those employed as keiyaku or haken in 2005 were aged 15-34 (Statistics Bureau 2005). Because these positions are short-term, do not guarantee continued employment, and do not offer long-term security, they do not necessarily provide incumbents the sustained self-sufficiency preferred before starting a family. Thus, other things being equal, as the proportion of entry-level jobs that are fixed-term or temporary increases, we would expect the age at first birth to be postponed. The risk of being an unemployed parent, especially if it was the father who was likely to be unemployed, would probably lead prospective parents to think twice before deciding to have a child. GutiérrezDomènech (2008) finds some evidence for this in Spain.

There are also reports of an increase in underemployment, perhaps related to increases in university graduates. For example, in Sweden, the per cent of workers overqualified for their jobs almost doubled from the 1940-44 birth cohort to the 1960-65 birth cohort (Bygren et al. 2005). Underemployment in general, and perhaps especially among men, would be expected to lead to the postponement of childbearing.

The matching process itself between those leaving school and employers looking to hire is critical. Some countries have dual system apprenticeship programs whereby young adults are spending part of their time in school and part in an apprenticeship program at a firm. Austria, Germany, the Netherlands and Denmark have such dual system programs, and enjoy relatively low youth unemployment rates (Pfeiffer and Nowak 2001; Scherer 2005). In Japan, schools play an important role in placing students in their first job after leaving school (Inui 2003; Ishida 1998; Ishida et al. 1997; Kerckhoff 1995). For most of the past 40 years, the "new graduate recruitment system" has been the principal mechanism whereby young Japanese men and women obtain their first job. Under this system, schools (both high schools and universities) act as go-betweens in the recruitment process for 'regular' jobs - jobs that are considered full-time, offer fringe benefits and fall under the lifetime employment model. By contrast, Italy has a relatively high level of youth unemployment, especially among those with high levels of education. This may be partly because schools are not involved in the job search process, and partly due to an atmosphere where waiting for a job that matches their skills leads to higher status jobs as well as less job turnover after they obtain their first job (Bernardi et al. 2004; Scherer 2005).

Empirical data regarding the length of the transition from school to work relative to age at first birth comes largely from two areas. First, as mentioned above, there is considerable evidence linking characteristics of the education system and the labour market to the length of this transition period. Since it is expected that most young people, especially males, want to be employed for some 
time period before starting a family, lengthening the transition from school to work should be expected to lead to later childbearing. Second, there is research investigating the link between (un)employment and childbearing. In virtually all the countries included in this paper, experiencing unemployment delays entry into fatherhood (Bernardi and Nazio 2005; Kurz et al. 2005; Tolke and Diewald 2003). For women the story is more complex, and probably related to unmeasured country level factors. On the one hand, in the Netherlands, Sweden, the United States and Spain, higher macro-level unemployment rates have been linked to delayed fertility (Hoem 2000; King 2005; Liefbroer 2005; Noguera et al. 2005). On the other hand, in Britain and Spain unemployed women are more likely to become mothers than their employed counterparts (Francesconi and Golsch 2005; Noguera et al. 2005).

\section{Work: re-entry}

The previous section discussed the transition to first job. For women, another key aspect of the transition to parenthood, especially among those with higher education levels, is the potential transition back into the labour market after having had one or more children. With few exceptions, mothers take some time away from their jobs after the birth of a child-although it can be as short as a few days or weeks. Prospective parents must then weigh the benefits of being young parents and experiencing fewer transitions (i.e. having a child before entering the labour market) against those of working and creating a more sound financial environment before having children (i.e. working for a few years and then leaving to have a child and perhaps reentering the labour market at a later point). Under various types of maternity leaves and related policies, mothers might keep their jobs and return to them.

The Scandinavian countries are often cited for their generous family leave policies. However, while these policies can ease women's reentry into work, they can also be responsible for delay in entering parenthood. In order to take advantage of these benefits women must have been working for a set amount of time (Rønsen and Sundström 2002). In Sweden, for example, the level of paid benefits during maternity leave is determined by time worked and level of wages prior to the beginning of the maternity leave, with the so-called "speed premium" potentially extending the level of paid maternity benefits to subsequent maternity leaves depending on the length of inter-birth intervals (Hoem 1993; Andersson et al. 2006).

In all countries, many women, including those without maternity leave benefits and those who choose to extend their time at home beyond that allowed under their specific leave policy, will leave their job upon the birth of their first child with the intention of returning to the labour force at a time they deem appropriate. For these women, many of the issues of the school-to-work transition 
are again relevant. Consider the case of Japan. With schools playing an important role in the match between job seekers and employers, mothers wishing to return to the labour market are by definition not recent graduates and thus will not have the assistance of their school. This exacerbates the difficulty mothers face when returning to the job market.

As with the education system, the overall openness of the labour market may also be important. Empirical research, focused largely on the United States, has found that mothers suffer a substantial penalty when they return to the labour market (Budig and England 2001; Correll et al. 2007; England 2005). Wages are lower and career paths are often derailed as a result of absences from work that are linked to childrearing.

To the extent that such aspects of the labour market are known to those who consider becoming a mother, and we expect that they are, prospective mothers might postpone childbearing in the face of considerable uncertainty regarding the ability to find an appealing job after taking time out for childrearing. The more general point is: the easier it is for mothers to reenter the labour force with an appealing job, the younger they are likely to be when they start having children.

\section{Jobs versus careers}

The higher the level of education obtained by a young person the greater the likelihood that they will want a career as opposed to simply having a job. Careers generally start with positions that are labelled "assistant" or "junior," which, as stepping stones along a career trajectory, tend to have low pay and high job insecurity. Indeed, for the initial job on a career ladder, the pay can be less than a non-career, 'dead-end' type job. But, careers typically lead to positions with stability, financial security and tenure or its equivalent. Given this stepping-stone trajectory, disruptions due to childbearing and rearing can have long-term consequences on one's career, and it is primarily women who experience such disruptions. Returning to the labour force after childbearing and early childrearing, women who had started on a given career path may find that they need to start over or might not even be able to start again. To the extent that knowledge about the dangers of interrupted work for career trajectories is wellknown, we expect that women will postpone their childbearing until they have reached that step on the job ladder which allows them to return with the highest probability of resuming their career. An alternative is to integrate childrearing into their lives such that they do not have to interrupt their career, but doing so depends on the nature of the specific job, the labour market, child care availability and the normative structure regarding mothers of young children being in the labour force.

The availability of part-time jobs is a factor cited to ease mothers' reentry into the labour market (e.g. Rosenfeld 1996). But part-time jobs tend not to be 'career' 
type jobs. Hakim (2007) describes an exception in the Netherlands where a joint effort among the government, trade unions and employers led to the creation of professional, career-type, part-time jobs. We expect that the availability of such jobs would ease the problem of mothers re-entering the labour market and permit those with career aspirations to become mothers at younger ages.

\section{Housing}

Characteristics of the housing market are also related to the transition to parenthood (Feijten and Mulder 2002; Mulder 2006a and 2006b; Murphy and Sullivan 1985; Schröder 2008). The inability to obtain appropriate living quarters is likely to postpone childbearing (as well as marriage and/or cohabitation). For young people in most of the countries considered in this paper, establishing a household independent from their parents' has been an important life course transition on the road to adulthood, in general, and parenthood, in particular (Aassve et al. 2002; Goldscheider and Goldscheider 1989; Hajnal 1982; Iacovou 2002). Today, in the West, it appears that establishing (or being able to establish) an independent household may be a necessary pre-condition for having children. Looking at multiple countries including Scandinavia, western and southern Europe and the United States, Iacovou (2002) found that in virtually all of them only a negligible proportion of young people with children were living in their parental homes. The exceptions to this were Finland, Denmark and France where roughly 10 to 20 per cent of people aged 17-35 with children were living with their parents. Japan, where co-residence with parents after marriage is common, would also be an exception and we discuss it below.

When housing markets are tight it is harder for young people to obtain independent households. Separate studies of Sweden, the United States and Australia found that when housing costs are high individuals are less likely to be living as married couples than in virtually any other type of living situation (Haurin et al. 1993; Hughes 2003; Lauster 2006), and this, in turn, is liable to postpone the transition to parenthood.

The issue of affordable and accessible housing has several components. The first is the actual supply of housing units, both rental and owner-occupied. Some of the countries considered here can be characterised as densely populated, industrial (and post-industrial), and with few open areas available for new building. As a result, the existing housing stock cannot be readily increased by horizontally expanding urban areas. In addition, land use policies can further restrict the supply of land for housing expansion. The Netherlands is an example of a county with restrictive spatial policies (Mulder 2006b).

A second housing issue is mortgage availability (Chiuri and Jappelli 2003). When higher down payments are required it is more difficult for young people to purchase housing. There is a wide range in expected or required down payments 
across countries (Mandič 2008; Mulder 2006a and b). For example, in the 1980s minimum down payments were 50 and 40 per cent in Italy and Spain respectively. In the United States the minimum was 10 per cent, and in the United Kingdom it was as low as 5 per cent in the early 1990s. Given this, it is not surprising that age at first birth is much higher in Italy and Spain than in the United States or the United Kingdom.

Other aspects of financial markets also influence mortgage and housing availability. When lenders have limited information regarding the borrower's credit history, the risk to the lender is higher than if complete (or almost complete) information is available (Chiuri and Jappelli 2003; Jappelli and Pagano 2002). If lenders are unable to determine whether a potential borrower has previously defaulted on a loan they are likely to raise the costs of their loans to cover the increased risk. Mortgages are widely available in the United States, Canada and the United Kingdom, partly because full credit reports are obtainable by potential lenders. However, in France, Italy and Spain, among others, there are few companies compiling credit reports and, as such, lenders have more difficulty assessing the credit risk of potential borrowers. As a result, in these countries, mortgages are more difficult to obtain and/or more expensive, delaying some from obtaining independent housing and, in turn, delaying childbearing.

Additionally, the ease with which lenders can foreclose and otherwise enforce mortgage contracts influences both the willingness of lenders to give mortgages and the cost of the mortgage, and this varies substantially across countries (Mandič 2008; Mulder 2006b; Stephens 2000, 2003). At the extremes, the duration of mortgage foreclosures in Italy is 48 months, compared to 2.5 months in the Netherlands (Chiuri and Jappelli 2003). Compounding these processes are the more general characteristics of the judicial system. Belgium, Germany, Italy and Spain have relatively inefficient systems as well as lower levels of home ownership in contrast to Finland, the Netherlands and the United States (Chiuri and Jappelli 2003). ${ }^{8}$ The efficient systems serve to lower lenders' risk, making them more likely to lend at lower rates and to require lower levels of down payments, which, in turn, allows individuals to purchase a dwelling unit earlier.

Another factor that may make housing more or less affordable is the level of subsidies available - both formally and informally. There is substantial variation in housing subsidisation across the European Union, ranging from direct cash subsidies to rent control to various tax schemes (Aassve et al. 2007; Haffner 2002; Haffner and Oxley 1999; Stephens 2000, 2003), but quantifying and comparing these cross-country subsidisation schemes has proven elusive (Haffner 2002; Haffner and Oxley 1999; Mulder 2006a). One example of limited subsidisation is Spain, where state-supported assistance is rare and families typically play a significant role in helping young people gain physical

\footnotetext{
8 Using data from the Business International Corporation, a country risk organisation, Chiuri and Jappelli (2003) present a scale of judicial efficiency that reflects the "integrity of the legal environment as it affects business (p.862)."
} 
independence (Holdsworth and Solda 2002). When available, more formal options such as social or public housing and rent subsidies can hasten the transition to independent living for young people who lack the financial resources on their own (Aassve et al. 2007; Mandič 2008).

Home ownership is not the only way young adults can leave the parental household; they may also rent. In countries with the earliest ages at leaving home, such as the Scandinavian countries, young adults tend to move into inexpensive rental apartments or group living situations where they rent housing when they first leave their parental home (Aassve et al. 2007; Chiuri and Jappelli 2003; Haurin et al. 1997; Iacovou 2002). They then purchase their own homes some years later. In countries such as Italy and Spain, with the latest ages at leaving home and where individuals tend to move from their parents' home directly into couple-based households, they tend to purchase their first home in their late 30s or early 40s, with financing frequently provided by the couple's families rather than financial institutions (Mandič 2008; Mulder 2006b; Schröder 2008; Stephens 2000). In these southern European countries, owner occupancy rates are among the highest in Europe ( $75 \%$ or greater), which conversely means that there are relatively few rental units available (Mulder 2006b). To the extent that this leads to higher rental costs, one would expect later household formation and age at first birth. Some data from the United States suggests that high rental costs are associated with later household formation (Di and Liu 2006; Haurin et al. 1993).

Interpreting the existing empirical evidence regarding the relationship between the housing market and the timing of fertility is complicated by the fact that some research considers housing type whereas other looks at ownership. However, there is empirical support for the notion that housing availability and the timing of parenthood are related - even if the causality is ambiguous. Research on housing type shows that, generally, couples in single-family homes have faster entry into parenthood than those in apartments or other housing types (Mulder and Wagner 2001; Kulu and Vikat 2007). Research on ownership illustrates that there is considerable cross-country variation in the specifics of the relationship. In Finland and Germany, the timing of home ownership and parenthood are closely linked, with couples who recently moved into their own dwelling units having higher rates of first births (Mulder and Wagner 2001; Kulu and Vikat 2007). For these couples, the housing change may have occurred in anticipation of having children or because the couple desired children and felt they needed the space or security of their own home to have them. The presumed counterfactual, which has not been tested, is that if the couple had not been able to move or purchase a home they would not have had children. By contrast, in Norway the timing of home ownership was less closely related to the timing of fertility; recent movers were not at a greater risk of becoming parents than nonowners (Mulder and Wagner 2001).

One obvious exception to this discussion of the housing market is for countries like Japan where post-nuptial co-residence with the husband's parents 
(if the husband is the first-born male) is the expectation. When new couples are expected to live with the husbands' parents the renting or purchase of a dwelling unit is no longer a potential stalling point on the road to childbearing. However, for higher-parity sons the housing market is likely to play an important role in family formation behaviour as discussed above. On the other hand, there is evidence that, in Japan, the expectation of living with the husband's parents after marriage is viewed negatively by many Japanese women and is a contributing factor in the postponement of both marriage and childbearing (Rindfuss 2004).

\section{Conclusion}

In this paper we focused on three institutions - the educational system, the labour market and the housing market - and illustrated how different aspects of each may be related to the timing of the first birth. In general, we argue that when institutions are more open and accessible, allowing individuals to balance the complex interplay between being a student, working, establishing an independent household and rearing children, childbearing is likely to occur earlier. More specifically, we argue that the following all lead to younger childbearing: 1) an open education system whereby it is relatively easy to return to school after having dropped out for a while; 2) shorter, smoother, easier school-to-work transition; 3) easier re-entry into the labour market after having taken time out for childrearing or any other reason; 4) greater capability of integrating childrearing into a career; 5) easier ability to obtain a mortgage with a moderately small down payment, moderately low interest rate and a long time period over which to repay the loan; and 6) easier ability to rent a dwelling unit at an affordable price. Conversely, reversing any or all of these factors would lead, other things being equal, to postponement of childbearing. Further, most of the policies within the educational system, the labour market and housing institutions that affect fertility tempo probably do so inadvertently, and not because they were designed to influence the timing of parenthood.

The institutions we discussed do not operate in isolation from one another. Young people are navigating and interacting with multiple institutions simultaneously. As a result, how a given institution influences behaviour presumably depends on the specifics of other institutions - or to put it differently, statistical interactions are to be expected. For example, the cost of housing does not depend solely on the absolute level of housing costs, but also on the cost relative to individuals' income (Ermisch 1999; Haurin et al. 1993). If young people are not financially secure (perhaps because of high unemployment rates), it is possible that even though the housing market may be open and low-interest mortgages available they still may not be able to afford to establish their own households. Thus, across countries we may see variation in age at first birth because countries that are similar on one institutional factor may differ on 
another. Simply put, we cannot understand fertility behaviour based on the current composition of just one institution; rather it will be important to look at an array of institutional factors.

Fertility tempo and childbearing motivation. While no consensus has emerged on their importance, a variety of hypotheses have been proposed to explain the reasons women and men have children in post-industrial societies. ${ }^{9}$ Among those proposed are genetic predisposition (Morgan and King 2001), to have someone to love and care for (Bulatao 1981), to create social capital for the parents (Schoen et al. 1997), and to bring predictability and order to the life course (Friedman et al. 1994). Note that none of these theoretical arguments have strong components related to fertility tempo; instead they all relate to fertility quantum.

Only two variations on the "biological clock" logic address tempo issues. The first of these refers to awareness of the fecundity curve by young women, and to a lesser extent young men. This variation is not a reason for having children, but a reason for not waiting too long. The idea is that women are aware that fecundity declines at some point in their $30 \mathrm{~s}$, and that they want to have all their desired children prior to the time when fecundity impairments might limit their own ability to reach their desired parity. Exactly what age women and their partners expect their own fecundity to be a limiting issue is unknown, perhaps to them and certainly to us. But, given all the attention by the media to the "biological clock" issue, we assume that most couples expect they can wait until the woman is in her mid-30s. This is older than any of the mean ages at first birth shown in Figure 1, and hence, if concern about one's fecundity were the only concern, there would seem to be room for more postponement in these countries.

The second variation on the biological clock theme involves the parents of young women and men. Many members of this 'senior generation' would like to become grandparents. In addition to being aware of the biological clock facing their daughters (and sons), they are aware of their own biological clocks, including mortality as well as anticipated morbidity. As childbearing is pushed into the $30 \mathrm{~s}$ for successive generations, the expected time to become a grandparent gets pushed into the $60 \mathrm{~s}$ or even the $70 \mathrm{~s}$. Given the evolution in educational and on-the-job training required in contemporary low-fertility countries, parents would most likely want their children to defer parenthood at least until some time in their early 20s. But after their child reaches some age, $x$, they might start encouraging them to have children, with $\mathrm{x}$ likely to vary by socioeconomic status and country. While there is considerable anecdotal evidence supporting such speculation, exactly how much this might affect the behaviour of the younger generation is unclear.

Hence, the general point is that, perhaps with some exception for these two biological-clock arguments, postponement is perfectly consistent with the

\footnotetext{
9 This recognises that many of the reasons for having children in traditional agricultural societies, such as helping on the farm (e.g. Cain 1977; Robinson, Lee and Kramer 2008) or providing old-age assistance, are no longer salient.
} 
theoretical hypotheses proposed for why people have children in post-industrial societies. And, as Figure 1 at the beginning of this paper makes clear, there is still considerable room for further postponement in the countries considered here.

Research implications. This paper is self-admittedly a speculative one with empirical hints that the speculation is correct. As such, it raises more questions than it answers. The next steps need to be rigorous empirical work, but doing so will not be easy. First, comparable-country level data will be needed, but such data are not readily available at present. Part of the reason is that some of the concepts involved are difficult to operationalise, such as the ease of re-entering the labour force at a level comparable to that held at last exit. But, even if comparable data were available, the small number of countries combined with the large number of potentially important variables makes meaningful multivariate control difficult.

To the extent that our arguments are valid, it will be important to know how these institutional factors combine to influence fertility tempo. Are any of them sufficient by themselves to induce younger or older childbearing? For example, is a high degree of difficulty in obtaining a mortgage sufficient to lead to later childbearing, or does it need to be combined with longer and more difficult transitions from school to work?

Finally, can we separate the effects of policy and informal aspects of institutions from the effects due to cultural differences across countries (see Breen and Buchmann 2002)? In addition to being temporally and life-course specific, policies are also culturally specific. For instance, in Germany, there is a widespread expectation that women will leave the labour market for many years when they begin having children (Blossfeld 1997 and Pfau-Effinger 2000 as cited in Tolke and Diewald 2003). This creates a large childbearing disincentive for women who desire to work, especially highly educated women who have invested considerable resources in their education. Simply enacting a policy that guarantees a woman can return to the labour market at a similar wage and occupational level as the one she held before leaving may not be enough to actually change behaviour. The social norms regarding full-time maternal care of young children may be a more powerful influence on fertility. But we note that evidence from poor countries with high fertility suggests that fertility behaviours and desires can and do change in response to policy and program interventions (Brauner-Otto 2007; Freedman and Takeshita 1969; Thornton and Lin 1994). Logic extended, it is possible that policy changes (and the discussion that precedes them) can trigger ideational change.

\section{Acknowledgements}

Sarah Brauner-Otto's effort on this paper has been partly supported by a training grant from the National Institute of Child Health and Human Development 
(NIH/NRSA T32 HD07168) to the Carolina Population Center, the University of North Carolina at Chapel Hill. Thanks for helpful comments from Larry Bumpass, Jan Hoem, Mieke Jansen, Øystein Kravdal, Vegard Skirbekk, Tomáš Sobotka, Elizabeth Thomson, participants at the conference Can Policies Enhance Fertility in Europe, the Vienna Institute of Demography, December 6-7, 2007; workshop on Family Changes in Industrialized Countries, Windsor, United Kingdom, April 30-May 2, 2008; and the population seminar, East-West Center, Honolulu, HI, February 13, 2008.

\section{References}

Aassve, A., F. C. Billari, S. Mazzuco, and F. Ongaro. 2002. "Leaving Home: A Comparative Analysis of ECHP Data." Journal of European Social Policy 12(4): 25975.

Aassve, A., M. A. Davis, M. Iacovou, and S. Mazzuco. 2007. "Does Leaving Home Make You Poor? Evidence From 13 European Countries." European Journal of Population 23: 315-38.

Alton, A. and A. Massey. 1998. "Date of Birth and Achievement in GCSE and GCE A-Level." Educational Research 40: 105-9.

Andersson, G., J. M. Hoem, and A.-Z. Duvander. 2006. "Social Differentials in SpeedPremium Effects in Childbearing in Sweden." Demographic Research 14(4): 51-70.

Anderton, D. L., N. O. Tsuya, and L. L. Bean. 1987. "Intergenerational Transmission of Relative Fertility and Life Course Patterns." Demography 24(4): 467-80.

Axinn, W. G., Marin E. Clarkberg, and A. Thornton. 1994. "Family Influence on Family Size Preferences." Demography 31(1): 65-79.

Becker, G. S. 1981. A Treatise on the Family. Cambridge, Mass., Harvard University Press.

Bernardi, F., M. Gangl, and H. G. van de Werfhorst. 2004. "The From-School-to-Work Dynamics. Timing of Work and Quality of Work in Italy, the Netherlands, and the United States, 1980-1998." Estudio/Working Paper 2004/201.

Bernardi, F. and T. Nazio. 2005. "Globalization and the Transition to Adulthood in Italy." In: H.-P. Blossfeld, E. Klijzing, M. Mills, and K. Kurz (eds.) Globalization, Uncertainty and Youth in Society. London, Routledge, pp. 349-74.

Bernhardt, E., T. Noack, and T. H. Lyngstad. 2008. "Shared Housework in Norway and Sweden: Advancing the Gender Revolution." Journal of European Social Policy 18(3): 275-88.

Bianchi, S. M. 2000. "Maternal Employment and Time With Children: Dramatic Change or Surprising Continuity." Demography 34(4): 401-14.

Bianchi, S. M., J. P. Robinson, and M. A. Milkie. 2006. Changing Rhythms of American Family Life. New York, Russell Sage Foundation.

Billari, F. C. and H.-P. Kohler. 2004. "Patterns of Low and Lowest-Low Fertility in Europe." Population Studies 58(2): 161-76.

Blossfeld, H.-P., E. Klijzing, M. Mills, and K. Kurz (eds.) 2005. Globalization, Uncertainty and Youth in Society. London, Routledge. 
Bongaarts, J. and G. Feeney. 1998. "On the Quantum and Tempo of Fertility.” Population and Development Review 24(2): 271-91.

Brauner-Otto, S. R. 2007. "Health Services, Schools, Attitudes, and Contraceptive Use: Tests of a Theoretical Model Among Rural Nepalese.” PhD Dissertation, University of Michigan, Ann Arbor.

Breen, R. 2005. "Explaining Cross-National Variation in Youth Unemployment: Market and Institutional Factors." European Sociological Review 21(2): 125-34.

Breen, R. and M. Buchmann. 2002. "Institutional Variation and the Position of Young People: A Comparative Perspective." The Annals of the American Academy of Political and Social Science 580: 288-305.

Brzinsky-Fay, C. 2007. "Lost in Transition? Labour Market Entry Sequences of School Leavers in Europe.” European Sociological Review 23(4): 409-22.

Budig, M. J. and P. England. 2001. "The Wage Penalty for Motherhood." American Sociological Review 66: 204-25.

Bulatao, R. A. 1981. "Values and Disvalues of Children in Successive Childbearing Decisions." Demography 18(1): 1-25.

Bygren, M., A.-Z. Duvander, and M. Hultin. 2005. "Elements of Uncertainty in Life Course. Transitions to Adulthood in Sweden." In: H.-P. Blossfeld, E. Klijzing, Melinda Mills, and K. Kurz (eds.) Globalization, Uncertainty and Youth in Society London, Routledge, pp. 135-58.

Cain, M. T. 1977. "The Economic Activities of Children in a Village in Bangladesh." Population and Development Review 3(2): 201-27.

Chiuri, M. C. and T. Jappelli. 2003. "Financial Market Imperfections and Home Ownership: A Comparative Study." European Economic Review 47: 857-75.

Cook, T. D. and F. F. Furstenberg. 2002. "Explaining Aspects of the Transition to Adulthood in Italy, Sweden, Germany and the United States: A Cross-Disciplinary, Case Synthesis Approach" The Annals of the American Academy of Political and Social Science. 580: 257-287

Corijn, M. and E. Klijzing, eds. 2001. Transitions to Adulthood in Europe. Dordrecht, Kluwer Acadmic Publishers.

Correll, S. J., S. Benard, and I. Paik. 2007. "Getting a Job: Is There a Motherhood Penalty?” American Journal of Sociology 112(5): 1297-338.

Cunningham, J. and T. Macan. 2007. "Effects of Applicant Pregnancy on Hiring Decisions and Interview Ratings." Sex Roles 57: 497-508.

Di, Z. X. and X. Liu. 2006. "The Effects of Housing Push Factors and Rent Expectations on Household Formation of Young Adults.” Journal of Real Estate Research 28(2): 149-66.

DiPrete, T. A., S. P. Morgan, H. Engelhardt, and H. Pacalova. 2003. "Do Cross-National Differences in the Costs of Children Generate Cross-National Differences in Fertility Rates?" Population Research and Policy Review 22(5-6): 439-77.

Ekert-Jaffé, O., H. Joshi, K. Lynch, R. Mougin, and M. Rendall. 2002. "Fertility, Timing of Births and Socio-Economic Status in France and Britain: Social Policies and Occupational Polarization.” Population-E 57(3): 475-508.

Elzinga, C. H. and A. C. Liefbroer. 2007. "De-Standardization of Family-Life Trajectories of Young Adults: A Cross-National Comparison Using Sequence Analysis." European Journal of Population 23: 225-50.

England, P. 2005. "Gender Inequality in Labor Markets: The Role of Motherhood and Segregation.” Social Politics 12(2): 264-88. 
England, P. and N. Folbre. 2005. "Gender and Economic Sociology." In: N. J. Smelser and R. Swedberg (eds.) Handbook of Economic Sociology. Russell Sage Foundation and Princeton University Press, Second ed., pp. 627-49.

Ermisch, J. 1999. "Prices, Parents, and Young People's Household Formation.” Journal of Urban Economics 45: 47-71.

Feijten, P. and C. H. Mulder. 2002. "The Timing of Household Events and Housing Events in the Netherlands: A Longitudinal Perspective." Housing Studies 17(5): 773-92.

Folbre, N., J. Yoon, K. Finnoff, and A. S. Fuligni. 2005. "By What Measure? Family Time Devoted to Children in the United States." Demography 42(2): 373-90.

Francesconi, M. and K. Golsch. 2005. "The Process of Globalization and Transitions to Adulthood in Britain.” In: H.-P. Blossfeld, E. Klijzing, M. Mills, and K. Kurz (eds.) Globalization, Uncertainty and Youth in Society. London, Routledge, pp. 249-76.

Freedman, R. and J. Y. Takeshita. 1969. Family Planning in Taiwan: An Experiment in Social Change. Princeton, Princeton University Press.

Frejka, T. and T. Sobotka. 2008. "Overview Chapter 1: Fertility in Europe: Diverse, Delayed and Below Replacement." Demographic Research 19 (Special Collection 7: Childbearing Trends and Policies in Europe): 15-46.

Friedman, D., M. Hechter, and S. Kanazawa. 1994. "A Theory of the Value of Children." Demography 31: 375-401.

Gauthier, A. H. 2002. "Family Policies in Industrialized Countries: Is There Convergence?" Population 57(3): 447-74.

Gauthier, A. H. and F. F. Furstenberg. 2002 "The Transition to Adulthood: A Time Use Perspective." The Annals of the American Academy of Political and Social Science 580: 153-171.

Gauthier, A. H., T. M. Smeeding, and F. F. Furstenberg. 2004. "Are Parents Investing Less Time in Children? Trends in Selected Industrialized Countries." Population and Development Review 30(4): 647-71.

Goldscheider, F. K. and C. Goldscheider. 1989. "Family Structure and Conflict: NestLeaving Expectations of Young Adults and Their Parents." Journal of Marriage and the Family 51(1): 87-97.

Gutiérrez-Domènech, M. 2008. "The Impact of the Labour Market on the Timing of Marriage and Births in Spain.” Journal of Population Economics 21(1): 83-110.

Haffner, M. E. A. 2002. "Dutch Personal Income Tax Reform 2001: An Exceptional Position for Owner-Occupied Housing." Housing Studies 17( 3): 521-34.

Haffner, M. E. A. and M. J. Oxley. 1999. "Housing Subsidies: Definitions and Comparisons." Housing Studies 14(2): 145-62.

Hajnal, J. 1982. "Two Kinds of Preindustrial Household Formation System." Population and Development Review 8(3): 449-94.

Hakim, C. 2007. "Can We Reverse Fertility Decline in Modern Societies?” Manuscript.

Hank, K. and M. Kreyenfeld. 2003. "A Multilevel Analysis of Child Care and Women's Fertility Decisions in West Germany." Journal of Marriage and the Family 65(3): 584-96.

Hanlon, J. 1995. "The 'Sick' Woman: Pregnancy Discrimination in Employment." Journal of Gender Studies 4(3): 315-23.

Hantrais, L. 1997. “ Exploring Relationships Between Social Policy and Changing Family Forms Within The European Union.” European Journal of Population 13: 339-79. 
1999. "Socio-Demographic Change, Policy Impacts and Outcomes in Social Europe." Journal of European Social Policy 9(4): 291-309.

Haurin, D. R., P. H. Hendershott, and D. Kim. 1993. "The Impact of Real Rents and Wages on Household Formation." The Review of Economics and Statistics 75(2): 284-93.

Haurin, R. J., D. R. Haurin, P. H. Hendershott, and S. C. Bourassa. 1997. "Home or Alone: The Costs of Independent Living for Youth.” Social Science Research 26(2): $135-52$.

Hoem, B. 2000. "Entry into Motherhood in Sweden: The Influence of Economic Factors on the Rise and Fall in Fertility, 1986-1997." Demographic Research 2(4).

Hoem, J M. 1993. "Public Policy As the Fuel of Fertility: Effects of a Policy Reform on the Pace of Childbearing in Sweden in the 1980s." Acta Sociologica 36: 19-31.

Hoem, J. M., G. Neyer, and G. Andersson. 2006a. "Education and Childlessness: The Relationship Between Educational Field, Educational Level and Childlessness Among Swedish Women Born in 1955-59." Demographic Research 14(15): 331-80.

2006b. "Educational Attainment and Ultimate Fertility Among Swedish Women Born in 1955-59." Demographic Research 14(16): 381-404.

Holdsworth, C. and M. I. Solda. 2002. "First Housing Moves in Spain: An Analysis of Leaving Home and First Housing Acquistion." European Journal of Population 18: $1-19$.

Hughes, M. E. 2003. "Home Economics: Metropolitan Labor and Housing Markets and Domestic Arrangements in Young Adulthood." Social Forces 81(4): 1399-429.

Iacovou, M. 2002. "Regional Differences in the Transition to Adulthood." The ANNALS of the American Academy of Political and Social Science 580: 40-69.

Inui, A. 2003. "Restructuring Youth: Recent Problems of Japanese Youth and Its Contextual Origin." Journal of Youth Studies 6(2): 219-33.

Ishida, H. 1998. "Educational Credentials and Labour-Market Entry Outcomes in Japan." In: Y. Shavit and W. Müller (eds.) From School to Work: A Comparative Study of Educational Qualifications and Occupational Destinations. Oxford, Clarendon Press, pp. 287-309.

Ishida, H., S. Spilerman, and K.-H. Su. 1997. "Educational Credentials and Promotion Chances in Japanese and American Organizations." American Sociological Review 62: 866-82.

Jappelli, T. and M. Pagano. 2002. "Information Sharing, Lending, and Defaults: CrossCountry Evidence.” Journal of Banking and Finance 26(10): 2017-45.

Johnson, N. E. and S. Stokes. 1976. "Family Size in Successive Generations: The Effects of Birth Order, Intergenerational Change in Lifestyle, and Familial Satisfaction." Demography 13(2): 175-87.

Kerckhoff, A. C. 1995. "Institutional Arrangements and Stratification Processes in Industrial Societies." Annual Review of Sociology 15: 323-47.

Kieffer, A., C. Marry, M. Meron, and A. Solaz. 2005. "The Case of France: Family Formation in an Uncertain Labor Market.” In: H.-P. Blossfeld, E. Klijzing, M. Mills, and K. Kurz (eds.) Globalization, Uncertainty and Youth in Society. London, Routledge, pp. 105-34.

King, R. B. 2005. "The Case of American Women: Globalization and the Transition to Adulthood in an Individualistic Regime.” In: H.-P. Blossfeld, E. Klijzing, M. Mills, and K. Kurz (eds.) Globalization, Uncertainty and Youth in Society. London, Routledge, pp. 305-26. 
Klijzing, E. 2005. "Globalization and the Early Life Course. A Description of Selected Economic and Demographic Trends." In: H.-P. Blossfeld, E. Klijzing, M. Mills, and K. Kurz (eds.) Globalization, Uncertainty and Youth in Society. London, Routledge, pp. 25-50.

Kohler, H.-P., F. C. Billari, and J. A. Ortega. 2002. "The Emergence of Lowest-Low Fertility in Europe During the 1990s." Population and Development Review 28: 64180 .

Kravdal, Ø. and R. R. Rindfuss. 2008. "Changing Relationships Between Education and Fertility a Study of Women and Men Born 1940 to 1964." American Sociological Review 73(5):854-873.

Kulu, H. and A. Vikat. 2007. "Fertility Differences by Housing Type: The Effect of Housing Conditions or of Selective Moves?" Demographic Research 17(26): 775802.

Kurz, K., N. Steinhage, and K. Golsch. 2005. "Case Study Germany: Global Competition, Uncertainty and the Transition to Adulthood." In: H.-P. Blossfeld, E. Klijzing, M. Mills, and K. Kurz (eds.) Globalization, Uncertainty and Youth in Society. London, Routledge, pp. 51-82

Lauster, N. T. 2006. "A Room of One's Own or Room Enough for Two? Access to Housing and New Household Formation in Sweden, 1968-1992." Population Research and Policy Review 25: 329-51.

Liefbroer, A. C. 2005. "Transition From Youth to Adulthood in the Netherlands." In: H.P. Blossfeld, E. Klijzing, M. Mills, and K. Kurz (eds.) Globalization, Uncertainty and Youth in Society. London, Routledge, pp. 83-104

Lindbeck, A. and D. Snower. 2002. "The Insider-Outsider Theory: A Survey." Institute for Discussion of Labor (IZA), Bonn. Discussion Paper No. 534. «http://papers.ssrn.com/sol3/papers.cfm?abstract_id=325323».

Lutz, W. and V. Skirbekk. 2005. "Policies Addressing the Tempo Effects of Low-Fertility Countries." Population and Development Review 31(4): 699-720.

Lutz, W., V. Skirbekk, and M. R. Testa. 2006. "The Low-Fertility Trap Hypothesis: Forces That May Lead to Further Postponement and Fewer Births in Europe." Vienna Yearbook of Population Research: 167-92.

Mandič, S. 2008. "Home-Leaving and Its Structural Determinants in Western and Eastern Europe: An Exploratory Study.” Housing Studies 23(4): 615-36.

Marini, M. M. and P. J. Hodson. 1981. "Effects of Timing of Marriage and First Birth on the Spacing of Subsequent Births." Demography 18: 529-48.

Masser, B., K. Grass, and M. Nesie. 2007. “'We Like You, But We Don't Want You'The Impact of Pregnancy in the Workplace.” Sex Roles 57: 703-712.

McDonald, P. 2003. “ Family Policy." Encyclopedia of Population, eds. P. Demeny and G. McNicoll. New York, Macmillan.

Morgan, S. P. and R. B. King. 2001. "Why Have Children in the 21st Century? Biological Predisposition, Social Coercian, Rational Choice." European Journal of Population 17(1): 3-20.

Morgan, S. P. and R. R. Rindfuss. 1999. "Reexamining the Link of Early Childbearing to Marriage and to Subsequent Fertility." Demography 36(1): 59-75.

Mouw, T. 2005. "Sequences of Early Adult Transitions: A Look at Variability and Consequences." In: R. A. Setterson, F. F. Furstenberg, and R. G. Rumbaut (eds.) On the Frontier of Adulthood: Theory, Research and Public Policy. Chicago, University of Chicago Press, pp.256-291. 
Mulder, C. H. 2006a. "Home-Ownership and Family Formation." Journal of Housing and the Built Environment 21(3): 281-98.

- 2006b. "Population and Housing: A Two-Sided Relationship." Demographic Research 15(13): 401-12.

Mulder, C. H. and M. Wagner. 2001. "The Connections Between Family Formation and First-Time Home Ownership in the Context of West Germany and the Netherlands." European Journal of Population 17: 137-64.

Müller, W. 2005. "Education and Youth Integration into European Labour Markets." International Journal of Comparative Sociology 46: 461-85.

Murphy, M. and L. B. Knudsen. 2002. "The Intergenerational Transmission of Fertility in Denmark: The Effects of Number of Siblings (Full and Half), Birth Order, and Whether Male or Female." Population Studies 56: 235-48.

Murphy, M. and D. Wang. 2001. "Family-Level Continuities in Childbearing in LowFertility Societies.” European Journal of Population 17: 75-96.

Murphy, M. J. and O. Sullivan. 1985. "Housing Tenure and Family Formation in Contemporary Britain." European Sociological Review 1(3): 230-243.

National Center for Health Statistics. 1975. Vital Statistics of the United States 1970, Volume 1-Natality. Rockville, Maryland, National Center for Health Statistics.

Ní Bhrolcháin, M. 1992. "Period Paramount? A Critique of the Cohort Approach to Fertility." Population and Development Review 18(4): 599-629.

Nicoletti, C. and M. L. Tanturri. 2008. "Differences in Delaying Motherhood Across European Countries: Empirical Evidence From the ECHP." European Journal of Population 24(2): 157-83.

Nilsen, Ø. A. 2005. "Transitions to Adulthood in Norway." In: H.-P. Blossfeld, E. Klijzing, M. Mills, and K. Kurz (eds.) Globalization, Uncertainty and Youth in Society, London, Routledge, pp. 159-76.

Noguera, C. S., T. Castro Martín, and A. Soro-Bonmatí. 2005. "The Spanish Case: the Effects of the Globalization Process on the Transition to Adulthood." In: H.-P. Blossfeld, E. Klijzing, M. Mills, and K. Kurz (eds.) Globalization, Uncertainty and Youth in Society, London, Routledge, pp. 375-402

OECD. 2006. Education at a Glance. OECD Indicators - 2006 Edition. OECD Publishing.

Oppenheimer, V. K. 1988. "A Theory of Marriage Timing." American Journal of Sociology 94(3): 563-91.

. 1994. "Women's Rising Employment and the Future of the Family in Industrial Societies." Population and Development Review 20(2): 293-342.

Pfeiffer, C. and V. Nowak. 2001. "Transition to Adulthood in Austria." In: M. Corijn and E. Klijzing (eds.) Transitions to Adulthood in Europe. Dordrecht, Kluwer Academic Publishers, pp. 43-66.

Presser, H. B. 1988. "Shift Work and Child Care Among Young Dual-Earner American Parents." Journal of Marriage and the Family 50(1): 133-48.

Rindfuss, R. R. 2004. "The Family in Comparative Perspective." In: N. O. Tsuya and L. L. Bumpass (eds.) Marriage, Work, and Family Life in Comparative Perspective: Japan, South Korea, and the United States. Honolulu, University of Hawaii Press, pp. 134-44.

Rindfuss, R. R., M. K. Choe, M. M. M. Kabamalan, N. O. Tsuya, and L. L. Bumpass. 2008. Order Amidst Change: Work and Family Trajectories in Japan. Paper presented at the IUSSP Seminar on Early Adulthood in Time and Space: Multidimensional and Multilevel Perspectives, Paris, France 26-27 June. 
Rindfuss, R. R., D. Guilkey, S. P. Morgan, Ø. Kravdal, and K. B. Guzzo. 2007. "Child Care Availability and First Birth Timing in Norway." Demography 44(2): 345-72.

Roberts, G. 2007. "Similar Outcomes, Different Pathers: The Cross-National Transfer of Gendered Regulations of Employment." In: S. Walby, H. Gothfried, K. Gottschall, and M. Osawa (eds.) Gendering the Knowledge Economy. New York, NY, Palgrave McMillan, pp. 140-160.

Robinson, R. S., R. D. Lee, and K. L. Kramer. 2008. "Counting Women's Labour: A Reanalysis of Children's Net Production Using Cain's Data From a Bangladeshi Village." Population Studies 62(1): 25-38.

Rønsen, M. and M. Sundström. 2002. "Family Policy and After-Birth Employment Among New Mothers - A Comparison of Finland, Norway, and Sweden." European Journal of Population 18: 121-52.

Rosenfeld, R. 1996. "Women's Work Histories." In: L. Casterline and Foote (eds.) Fertility in the United States: New Patterns, New Theories. A Supplement to Population and Development Review. New York, Population Council.

Ryder, N. B. 1980. "Components of Temporal Variations in American Fertility." In: R. W. Hirons (ed.) Demographic Patterns in Developed Socities, vol. Symposia of the Society for the Study of Human Biology. London, Taylor and Francis.

- 1956. "Problems of Trend Determination During a Transition in Fertility." Milbank Memorial Fund Quarterly 34: 5-21.

- 1973. "Recent Trends and Group Differences in Fertility." In: Ch. F. Westoff (ed.) Toward the End of Growth. Englewood Cliffs, NJ, Prentic-Hall, pp. 57-68.

Scherer, S. 2005. "Patterns of Labour Market Entry - Long Wait of Career Instability? An Empirical Comparison of Italy, Great Britain and West Germany." European Sociological Review 21(5): 427-40.

Schoen, R., Y. J. Kim, C. A. Nathanson, J. Fields, and N. A. Aston. 1997. "Why Do Americans Want Children?" Population and Development Review 23: 333-57.

Schröder, C. 2008. Economic Insecurity and Cohabitation Strategies in Italy. Paper presented at the European Population Conference, 9-12 July, Barcelona, Spain.

Settersten, R. A. 2007. "Passages to Adulthood: Linking Demographic Change and Human Development." European Journal of Population 23: 251-272.

Shanahan, M. J. 2000. "Pathways to Adulthood in Changing Societies: Variability and Mechanisms in Life Course Perspective." Annual Review of Sociology 26: 667-92.

Sharp, C. 1995. "What's Age Got to Do With It? A Study of Patterns of School Entry and the Impact of Season of Birth on School Attainment." Educational Research 37: 25165.

Skirbekk, V., H.-P. Kohler, and A. Prskawetz. 2004. "Birth Month, School Graduation, and the Timing of Births and Marriages." Demography 41(3): 547-68.

Statistics Bureau. 2005. "Annual Report on the Labour Force 2005 (Detailed Tabulation)." Tokyo, Statistics Bureau, Japan Ministry of Internal Affairs and Communication.

. 2001. "Heisei-8-Nen 8-GatsuRoudo-Ryoku Chosa Tokubetsu-Chosa Kekka Sokuhou (Prompt Report of the Results of the Special Survey of the Labour Force Survey August 2001).” Tokyo, Statistics Bureau, Japan Ministry of Internal Affairs and Communication.

Steenhof, L. and A. C. Liefbroer. 2008. "Intergenerational Transmission of Age at First Birth in the Netherlands for Birth Cohorts Born Between 1935-1984: Evidence From Municipal Registers." Population Studies 62(1): 69-84. 
Stephens, Mark. 2000. "Convergence in European Mortgage Systems Before and After EMU." Journal of Housing and the Built Environment 15: 29-52.

2003. "Globalisation and Housing Finance Systems in Advanced and Transition Societies." Urban Studies 40(5-6): 1011-26.

Thornton, A. and H.-S. Lin. 1994. Social Change and the Family in Taiwan. Chicago, The University of Chicago Press.

Tolke, A. and M. Diewald. 2003. "Insecurities in Employment and Occupational Careers and Their Impact on the Transition to Fatherhood in Western Germany." Demographic Research 9(3): 41-68.

Veevers, J. 1971. "Childlessness and Age at First Marriage.” Social Biology 18(3): 292295.

Winkler-Dworak, M. and L. Toulemon. 2007. "Gender Differences in the Transition to Adulthood in France: Is There Convergence Over the Recent Period?" European Journal of Population 23: 273-314.

Wolbers, M. H. J. 2007. "Patterns of Labour Market Entry.” Acta Sociologica 50(3): 189210.

Yuji, G. 2005. A Nagging Sense of Job Insecurity. Tokyo, International House of Japan. 